\title{
The Relative Contribution of Habits of mind in predicting Achievement motivation for a sample of Assistant Lecturers in University
}

*Wesam Ibrahim Mohamed

\section{Abstract:}

The present study aimed to uncover the relationship between the habits of mind, "communicating with clarity and accuracy, striving for accuracy, learning continuously, sense of humor, listen with understanding and empathy, creativity, imagining and innovating, thinking interdependently and benefit from experience" to achievement motivation for a sample of assistant lecturers in university and to identify the contribution degree of the habits of mind in predicting achievement motivation with the study's sample of (200) members of assistant lecturers at Mansoura University, (100) males and (100) females with an average age of (26.18) and a standard deviation of $( \pm$ 2.4). The measure of the habits of mind was used (prepared by the researcher), and the measure of achievement motivation (prepared by the researcher). The results of the study showed that there is a statistically significant relationship between the habits of mind, "communicating with clarity and accuracy, striving for accuracy, learning continuously, sense of humor, listen with understanding and empathy, creativity, imagining and innovating visualization and innovation, thinking interdependently and benefit from experience" and the achievement motivation. The results of the multiple regression analysis showed that creativity, imagining and innovating, thinking interdependently, benefit from accuracy and striving for accuracy as one of the habit of mind having statistically significant contribution in predicting achievement motivation for assistant lecturers in universit

Key Words: Habits of Mind-Achievement Motivation-Assistant Lecturer in University.

\section{Introduction:}

* Assistant lecture Psychology Department, faculty of Arts - Mansoura University. Email: wesam ibrahim11@yahoo.com 


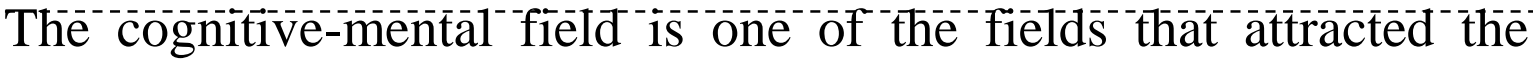
attention of many researchers in psychology. This led to the emergence of many trends and theories that tried to understand and interpret the human mind, which were divided into three directions: the traditional trend represented in studying the intelligence as a general mental ability, the trend to form and address cognitive information or processes, and the trend of multiple mental abilities or multiple intelligences (Abd ElHamid \& Abo Hashim, 2007: 172).

God Almighty promoted the value of the mind and distinguished the human beings from the rest of the living beings with the mind, and ordered in all religions to work and get used to using it and harness all its functions and capabilities in the reconstruction of the Earth, and if we contemplate the high levels of maturity and progress of the human civilizations in all fields, we find that they are the result of utilizing the mind, imagination and thinking at different levels (Arian, 2010: 2).

In the face of this rapid development of information, we highlight the importance of teaching the habits of mind, which are pointed out by Arthur Costa \& Kallick, pointing out that the behavior of individuals requires discipline of the mind being exercised, so that it becomes a normal way of working towards more attentive and intelligent actions (El-Rabighy, 2015: 57). In this sense, the call of modern education to utilize the mental habits such as eating, drinking, and sleep appeared, such as getting used to waking up early or use of Siwak while performing ablution (Wudhu), he should get used to mental strategies before doing any of his work (Nofal, 2006: 65).

The habits of mind represent the learned intellectual behaviors that are selected at certain times for the exercise of thinking, leading to productive action and becoming a normal way towards more intelligent acts. Mental habit refers to the way or behavior in which one uses or applies his thinking. Costa \& Kallick define the habits of mind as: the habits that manage organize and arrange the mental processes and develop the proper priorities system of these processes (Costa \& Kallick, 2000: 201).

Costa \& Kallick (2000: 2) provided a list of sixteen habits of mind (perseverance, fluency control, listening with understanding and empathy, thinking flexibly, thinking about thinking, striving for accuracy, questioning and posing problems, applying past knowledge to 
new situations, communicating clearly, gathering data using the senses, learning continuously, thinking interdependently, taking responsible risks, thinking communicating clearly and accurately, responding with surprise and awe and finding humor).

In the view of Costa \& Kallick (2005: 4), the habits of the mind are the tendency of the individual to behave intelligently when confronted with a problem, when the solution and the answer are not available in its cognitive structure. The problem may be in the form of a confusing situation or puzzle, the habits of minds help to employ the intelligent behavior when the individual does not know the appropriate solution or answer.

Costa \& Kallick (2000: 201) point out that the negligence of the use of the habits of mind causes many deficiencies in the outcomes of the learning process, as the habits of mind are not the possession of information and focus on how much knowledge is gained only, but is the employment of information and how to use it and develop dealing with contemporary technologies, which imposes on the individual to follow the developments and progress in various field, the habits of mind are necessary for effective thinking as individuals who are familiar with these habits are not only able to think deeply, but their mental habits help them to reach the mental abilities necessary to solve problems when needed, while "Horseman" resemble the habits of mind with rope whose yarns are weaved every day until it becomes thick and difficult to cut, and therefore the habits of mind according to Horseman's conception is an evolutionary process with results that ultimately hope to lead to the production of ideas and problem solving (Costa \& Kallick, 2003: 23) The definition is that the habits of mind are a sequential evolutionary process aimed at helping the individual to enter into the realm of intelligent habits and behaviors that ultimately lead to production and innovation. (Adams, 2006: 14).

The habits of mind are a set of skills, attitudes, past experiences and tendencies. The purpose of teaching these habits is that the trainees become more willing to use them when faced with conditions that lack certainty or are surrounded with challenge. As the motivation study is one of the main axes of psychology, the achievement motivation represents one of the important aspects of the individual as it is one of the personal components that have a clear role in the behavior of the individual, through its linkage to a range of important variables, and the 
The Relative Contribution of Habits of mind in predicting Achievement motivation for a sample of Assistant

Lecturers in University.

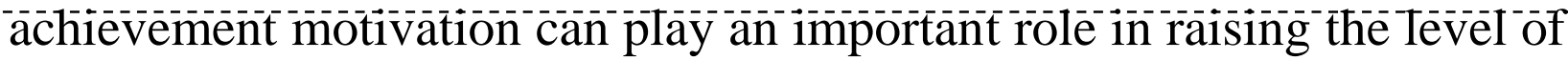
individual performance and productivity in various fields and activities which he faces (El-Rabighy, 2015: 115).

Atkinson's theory sees that the individual's expectation of his performance and his self-awareness of his ability and consequences are mutual cognitive relationships that stand behind the behavior of achievement, and that highly motivated individuals make great efforts in trying to solve problems. Atkinson asserts that the tendency to succeed is an educated matter and it is differentiated between individuals, and differs in individual situations. These motivations are influenced by three main factors when an individual performs a task. These factors are related to the motivation to achieve success, the probabilities of success associated with task difficulty, and the motivational value (Petri \& Govern, 2004)

The achievement motivation with the individual is a personal component that has a clear role in the behavior of the individual, through the association with a range of important variables, and the achievement motivation can play an important role in raising the level of individual performance and productivity in various fields and activities which he face. The scientists confirm that any human behavior must be aroused and directed by a motivation or motivation. The achievement motivation includes different types and patterns of behavior. Therefore, attention has been paid to its relation to social, educational and psychological variables. It attempts to identify factors that contribute significantly to the interpretation of variance in achievement motivation among individuals.

The achievement motivation is positively associated with socialization, independence and self-confidence. The achievement motivation is a self-directed goal that activates and directs an individual's behavior. Individuals with high achievement are described as being inclined to make serious attempts to obtain great deal of success in many situations. The achievement motivation affects the determination of the individual's level of education. It acts as an additional force that directs the behavior of individuals towards achieving their hopes, which leads them to increase their knowledge and develop their skills (El-Rabighy, 2015: 13). 
As for the previous studies, the researcher did not find, in the limitations of her knowledge, only one study conducted in the Saudi environment, conducted by (Al-Qudah, 2014). The results showed that there is a statistically significant relationship between the habits of mind and achievement motivation. The study's findings showed also that creativity, imagining and innovating as one of the habits of mind have contributed statistically to the prediction of achievement motivation.

\section{Study Problem:}

In spite of the numerous studies that dealt with the habits of the mind in relation to various variables such as the study of (El-Tantawy, 2017; Abd El-Raouf, 2016; Abd El-Wahab, Al-Waily, 2010; AlShemari, 2010; Abd El-moaty, 2018; Mahmoud, 2018) but most of the studies were conducted on the university's students such as the study of (Al-Karki, 1996; Al-Fattah, 2017; Tayseer \& Ahmed, 2011) and secondary students such as (Abdullatif, 2015; El-Rabighy 2007); and students of the primary stage (Arndt, 2009; Salama \& Rasmi, 2012; Culler, 2007; Hajat, 2008). There is no study cares about the sample of the current study, and it most of them are limited on the relationship's study as followed in these studies and they don't care about the predictability. The researcher also noted the scarcity of previous studies on the subject of the study, despite the existence of theoretical attribution for this matter, and it enhances the originality of the present study.

The study problem can be determined in the following questions:

1.Is there a relationship between the habits of mind, "communicating with clarity and accuracy, striving for accuracy, learning continuously, sense of humor, listen with understanding and empathy, creativity, imagining and innovating, thinking interdependently and benefit from experience" and the total score of achievement motivation of the study's sample?

2. Is it possible to predict Achievement Motivation Through University Assistants Lecturers scores in Habits of Mind?

\section{Study hypotheses:}

\section{The study hypotheses can be formulated as follows:}




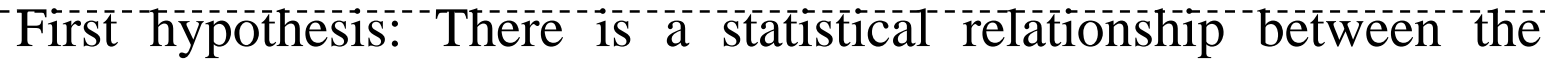
habits of mind, "communicating with clarity and accuracy, striving for accuracy, learning continuously, sense of humor, listen with understanding and empathy, creativity, imagining and innovating, thinking interdependently and benefit from experience" and the total score of achievement motivation of the study's sample.

Second hypothesis: It is possible to predict achievement motivation through the sample of the study scores in the habits of mind, ""communicating with clarity and accuracy, striving for accuracy, learning continuously, sense of humor, listen with understanding and empathy, creativity, imagining and innovating, thinking interdependently and benefit from experience".

\section{Study Methodology and its procedures:}

A- Method used in the current study: descriptive correlation approach.

B- Sample of the study: consisted of (200) members of assistant lecturers in the university, (100) males, (100) females, ages ranged between (24-29) years, with an average age of (26.18) years and a standard deviation of $( \pm 2.4)$.

\section{C- Sample characteristics :}

1. In terms of type (male - female): The study sample consists of (100) male members, (100) female members..

2. Distribution of the sample population in terms of colleges: The study sample consists of (100) members from some practical colleges, (100) members from some theoretical colleges.

3. Distribution of the sample population in terms of job: The study sample consists of (200) members of the Assistant Lecturers University, (100) male members divided into (50) Demonstrators, (50) assistant Lecturers, (100) females divided into (50) Demonstrators , (50) Assistant Lecturers.

\section{D- Study Tools:}

(First) Measure of habits of mind: Prepared by the researcher 
The sample of the pilot study, which was conducted on all the reliability and validity coefficients for all scales of the current study, consisted of (120) members of the assistant lecturers and they have the same characteristics of the current study sample.

\section{Steps to prepare habits of mind scale:}

The Arab and foreign theoretical frameworks and previous studies have been reviewed to define a procedural concept of the habits of the mind of the members of the university's Assistant Lecturers The questionnaire included the following questions:

A- What are the skills or behaviors that you use in facing the tasks that are required of you in your work?

B- What skills do you use in dealing with those around you (friends - supervisor - co-workers)?

C- Considering that you are a member of the assisting Lecturers University, and preparing a "Master - Doctorate" thesis, what skills do you use and help you succeed in preparing your thesis?

From the responses of the Participants, the researcher was able to formulate a set of Items. The scale was presented in its initial form to some of the Professors specialized in the field of psychology and mental health to provide their opinions on the formulation of phrases, the extent of their suitability to the axis you belong to, and the exclusion of inappropriate and repetitive Items.

Although there are several measures in the habits of the mind, the researcher did not use these Scales that she viewed, because some of them were prepared in different cultures, while others were prepared for university students such as (Al-Shammari, 2010; Salama, and Rasmi, 2012), And some were prepared on kindergarten teachers (Abbas and Faisal, 2015). Also, some of these Scales contain some statements that are not appropriate for the current study sample.

\section{Scale validity}

- Factor validity of the scale of the habits of mind 


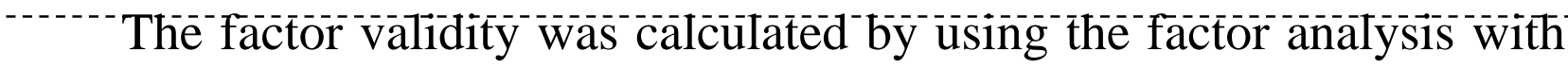
the method of principal components of Hottelling and the orthogonal rotation of the axes using Varimax. The factor analysis of the scale's items resulted in the emergence of eight factors "communicating with clarity and accuracy, striving for accuracy, learning continuously, sense of humor, listen with understanding and empathy, creativity, imagining and innovating, thinking interdependently and benefit from experience", (intrinsic root value of each) and (correlation variance ratio) respectively: $2,82(4.03 \%), 2.43(3.47 \%), 2.48$ (3.54\%), 2.49 (3.55\%), $2.15(3.07 \%), 1.38(1.97 \%), 1.36(1.94 \%), 1.21(1.73 \%),(6)$ items. The factor analysis resulted in the exclusion of (6) items. Table (1) shows the fundamental determinants of the eight factors that were extracted after the orthogonal rotation using Varimax method in the measure of the habits of mind.

\section{- Criterion validity:}

The criterion validity was calculated by using the scale of the habits of mind prepared by (Abbas \& Faisal, 2015), the value of correlation coefficient between the scale of the habits of mind (Abbas\& Faisal, 2015 ) for the eight usually ranged between (0.72-0.88).

\section{Calculating the reliability of the habits of mind sacle:}

The values of the habits of mind scale were calculated by splithalf and correcting the length by the Spearman Brown correlation coefficient. The correlation coefficient values for the eight usually ranged between (0.65-0.82). The reliability values using alpha coefficient of the eight were usually between (0.61-0.79).

\section{- The habits of mind scale in its final form:}

This scale consists of 64 phrases with three alternatives to respond from (3) I agree to (1) Disagree, and the overall score of communicating with clarity and accuracy, and striving for accuracy ranges between (927 ), the total score of learning continuously and sense of humor of (824) and the overall score of listening with understanding and empathy (10-30), the overall score of creativity, imagining and innovating, thinking interdependently (7-21), and benefit from experience (6-18). 


\begin{tabular}{|c|c|c|c|c|c|c|c|c|c|c|c|c|c|c|c|}
\hline \multicolumn{16}{|c|}{ Table (1) } \\
\hline \multicolumn{16}{|c|}{ Loadings of items on the eight factors after rotation } \\
\hline Item Number & 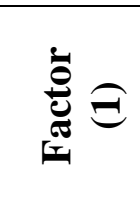 & 窇 & 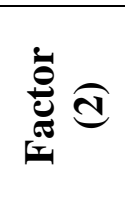 & 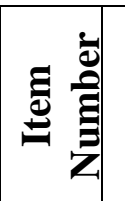 & 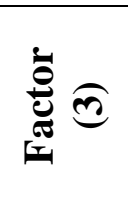 & 焉咅 & 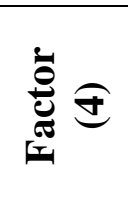 & 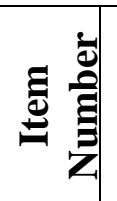 & 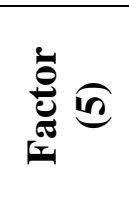 & 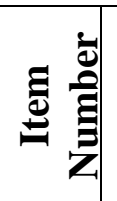 & 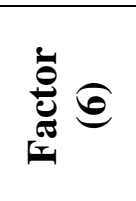 & 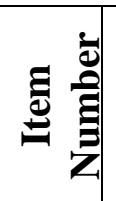 & 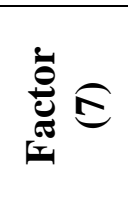 & 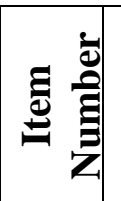 & 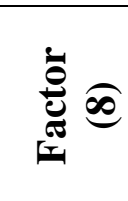 \\
\hline 1 & 0.65 & 10 & 0.62 & 19 & 0.74 & 27 & 0.64 & 35 & 0.64 & 45 & 0.55 & 52 & 0.62 & 59 & 0.54 \\
\hline 2 & 0.65 & 11 & 0.58 & 20 & 0.72 & 28 & 0.64 & 36 & 0.57 & 46 & 0.48 & 53 & 0.55 & 60 & 0.53 \\
\hline 3 & 0.63 & 12 & 0.56 & 21 & 0.57 & 29 & 0.63 & 37 & 0.55 & 47 & 0.47 & 54 & 0.44 & 61 & 0.47 \\
\hline 4 & 0.56 & 13 & 0.55 & 22 & 0.54 & 30 & 0.54 & 38 & 0.49 & 48 & 0.46 & 55 & 0.40 & 62 & 0.39 \\
\hline 5 & 0.56 & 14 & 0.54 & 23 & 0.47 & 31 & 0.54 & 39 & 0.44 & 49 & 0.42 & 56 & 0.34 & 63 & 0.38 \\
\hline 6 & 0.52 & 15 & $\mathbf{0 . 5 3}$ & 24 & 0.47 & 32 & 0.51 & 40 & 0.42 & 50 & 0.37 & 57 & 0.34 & 64 & 0.34 \\
\hline 7 & 0.51 & 16 & 0.51 & 25 & 0.44 & 33 & 0.49 & 41 & 0.37 & 51 & 0.32 & 58 & $\mathbf{0 . 3 0}$ & & \\
\hline 8 & 0.49 & 17 & 0.44 & 26 & 0.41 & 34 & 0.44 & 42 & 0.36 & & & & & & \\
\hline \multirow[t]{2}{*}{9} & 0.43 & 18 & 0.43 & & & & & 43 & 0.35 & & & & & & \\
\hline & & & & & & & & 44 & $\mathbf{0 . 3 3}$ & & & & & & \\
\hline "Eigenvalue" & 2.82 & \multicolumn{2}{|c|}{2.43} & \multicolumn{2}{|c|}{2.48} & \multicolumn{2}{|c|}{2.49} & \multicolumn{2}{|c|}{2.15} & \multicolumn{2}{|c|}{1.38} & \multicolumn{2}{|c|}{1.36} & \multicolumn{2}{|c|}{1.21} \\
\hline Percentages of Variance & $4.03 \%$ & \multicolumn{2}{|c|}{$3.47 \%$} & \multicolumn{2}{|c|}{$3.54 \%$} & \multicolumn{2}{|c|}{$3.55 \%$} & \multicolumn{2}{|c|}{$3.07 \%$} & \multicolumn{2}{|c|}{1.97} & \multicolumn{2}{|c|}{1.94} & \multicolumn{2}{|c|}{1.73} \\
\hline
\end{tabular}

\section{(Second) Achievement motivation scale: Prepared by the research}

\section{Steps to prepare Achievement motivation scale:}

Although the psychological library contains many measures of achievement motivation, the researcher did not find a scale that is interested in the study sample, most of the standards concerned the university students and

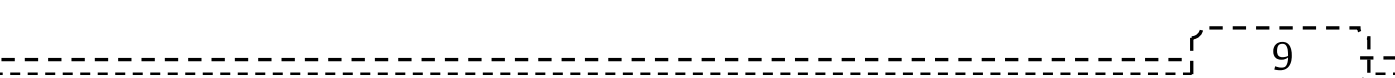


The Relative Contribution of Habits of mind in predicting Achievement motivation for a sample of Assistant Lecturers in University.

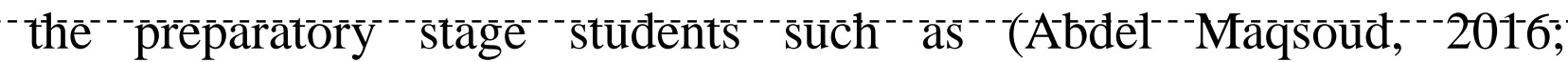
Mousa,1987) and some of them went through a period A long time, therefore, the researcher prepared a measure of achievement motivation that suits the members of the Assistant Lecturers in University.

\section{1- Scale validity:}

\section{- The factor validity of achievement motivation scale:}

The scale validity was calculated using factor analysis in the manner of the basic components of Hottelling with the orthogonal rotation of the axes using Varimax method. The factor analysis of the scale's items revealed three factors and they are: planning for the future, perseverance and seeking superiority. The latent root value "Eigenvalue" of each (Correlation variance ratio) respectively: 2.91 (7.09\%), 2.91 (7.09\%), $2.23(5.43 \%)$. The factor analysis resulted in the exclusion of (10) items. Table (2) shows the fundamental determinants of the three factors that were extracted after the orthogonal rotation in the Varimax method in the motivation scale for achievement motivation.

\section{- Criterion validity:}

The criterion validity was calculated using the achievement motivation scale (prepared by Eid, 2015). The correlation coefficient between the achievement motivation scale (prepared by the researcher) and the achievement motivation scale (prepared by Eid, 2015) is 0.83.

\section{scale: \\ 2- Calculating the reliability of the achievement motivation}

Reliability of the scores of the achievement motivation scale was calculated by split-half and correcting the length by the Spearman Brown correlation coefficient. The correlation coefficient value was equal to (0.82). The reliability value using the Kronbach coefficient was (0.77).

\section{- Internal consistency of the achievement motivation scale:}

The internal consistency was calculated by calculating the correlation coefficient between the score on the phrase and the dimension to which it belongs, as well as the correlation coefficient between the degree on the dimension and the total score on the scale. This step resulted in excluding an item whose correlation coefficient was less than the significance level, so the scale becomes 30 phrases. 


\section{Achievement motivation scale in its final form:}

This scale consists of 30 phrases with three alternatives to respond from (3) I agree, to (1) disagree, and the total score ranges between (30-90).

Table (2)

Loadings of items on the three factors after rotation

\begin{tabular}{|c|c|c|c|c|c|}
\hline Item Number & $\begin{array}{c}\text { Factor } \\
\text { (1) }\end{array}$ & $\begin{array}{c}\text { Item } \\
\text { Number }\end{array}$ & $\begin{array}{c}\text { Factor } \\
\text { (2) }\end{array}$ & $\begin{array}{c}\text { Item } \\
\text { Number }\end{array}$ & $\begin{array}{c}\text { Factor } \\
\text { (3) }\end{array}$ \\
\hline 1 & 0.66 & 11 & 0.60 & 23 & 0.65 \\
\hline 2 & 0.61 & 12 & 0.60 & 24 & 0.59 \\
\hline 3 & 0.58 & 13 & 0.58 & 25 & 0.55 \\
\hline 4 & 0.56 & 14 & 0.54 & 26 & 0.50 \\
\hline 5 & 0.55 & 15 & 0.52 & 27 & 0.49 \\
\hline 6 & 0.53 & 16 & 0.50 & 28 & 0.47 \\
\hline 7 & 0.52 & 17 & 0.47 & 29 & 0.44 \\
\hline 8 & 0.52 & 18 & 0.46 & 30 & 0.40 \\
\hline 9 & 0.43 & 19 & 0.45 & 31 & 0.31 \\
\hline 10 & 0.38 & 20 & 0.43 & & \\
\hline & & 21 & 0.36 & & \\
\hline & & 22 & 0.31 & & \\
\hline "Eigenvalue" & 2,91 & & 2.91 & \multicolumn{2}{|c|}{2.23} \\
\hline $\begin{array}{l}\text { Percentages } \\
\text { of Variance }\end{array}$ & $7.09 \%$ & & $7.09 \%$ & \multicolumn{2}{|c|}{$5.43 \%$} \\
\hline
\end{tabular}

\section{Procedures:}

The study tools were applied to (200) members of assistant lecturers during the academic year 2017/2018, which were selected by the accidental random sample method, it is the sample whose respondents are chosen accidentally, i.e. without any previous arrangement and the researcher chooses its respondents because this is available to him (Luis Cohen, Lawrence Manyon, 1990: 130). Spss version 20 was used for statistical data analysis. The following statistical methods were used: descriptive statistics, Pearson correlation coefficient, and regression analysis.

\section{Results:}

First hypothesis: There is a statistical relationship between the habits of mind: "communicating with clarity and accuracy, striving for accuracy, 
The Relative Contribution of Habits of mind in predicting Achievement motivation for a sample of Assistant Lecturers in University.

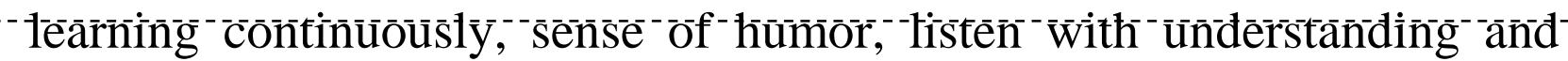
empathy, creativity, imagining and innovating, thinking interdependently and benefit from experience" and the total score of the achievement motivation of the study's sample. Table (3) shows the values of the correlation coefficients " $r$ " between the respondents' scores on the dimensions of the scale of the habits of mind and the total score of the achievement motivation scale.

\section{Table (3)}

Values of correlation coefficients " $r$ " between the scores of the respondents on the dimensions of the habits of mind and the total score of the achievement motivation

\begin{tabular}{|l|c|}
\hline \multicolumn{1}{|c|}{$\begin{array}{c}\text { Achievement } \\
\text { motivation }\end{array}$} & "r" \\
Dimensions of habits of mind & \\
\hline Communicating with clarity and accuracy & $* * 0.43$ \\
\hline Striving for accuracy & $* * 0.46$ \\
\hline Learning continuously & $* * 0.50$ \\
\hline Sense of humor & $* * 0.44$ \\
\hline Listen with understanding and empathy & $* * 0.40$ \\
\hline Creativity, imagining and innovating & $* * 0.53$ \\
\hline Thinking interdependently & $* * 0.50$ \\
\hline Benefit from experience & $* * 0.51$ \\
\hline
\end{tabular}

It is clear that there is a positive relationship between "communicating with clarity and accuracy, striving for accuracy, learning continuously, sense of humor, listen with understanding and empathy, creativity, imagining and innovating, thinking interdependently and benefit from experience" and the total score of the achievement motivation at level 0.01.

Second hypothesis: The achievement motivation can be predicted through the scores of the study's sample scores in the habits of mind "communicating with clarity and accuracy, striving for accuracy, learning continuously, sense of humor, listen with understanding and empathy, creativity, imagining and innovating, thinking interdependently and benefit from experience". Table (4) shows the results of the multiple regression analysis, values of the relative contribution, $F$ ratio and statistical significance of the habits of mind in predicting the achievement motivation 
Table (4)

Results of the multiple regression analysis, values of the relative contribution, $F$ ratio and statistical significance of the habits of mind in predicting the achievement motivation

\begin{tabular}{|c|c|c|c|c|c|c|c|c|c|c|c|c|c|c|}
\hline $\begin{array}{c}\text { Dependent } \\
\text { variable }\end{array}$ & $\begin{array}{c}\text { Predictor } \\
\text { variable }\end{array}$ & $\mathrm{R}^{2}$ & & $\begin{array}{c}\text { Total } \\
\text { squares }\end{array}$ & $\begin{array}{c}\text { Freedom } \\
\text { degrees }\end{array}$ & $\begin{array}{l}\text { Average } \\
\text { of } \\
\text { squares }\end{array}$ & $\begin{array}{c}\text { "F" } \\
\text { value }\end{array}$ & Significance & Model & $\begin{array}{c}\text { Standard } \\
\text { correlation } \\
\text { value }\end{array}$ & $\begin{array}{c}\text { Standard } \\
\text { error }\end{array}$ & $\begin{array}{c}\text { Beta } \\
\text { "Contribution } \\
\text { value" }\end{array}$ & $\begin{array}{l}\text { "T" } \\
\text { value }\end{array}$ & Significance \\
\hline \multirow{4}{*}{ 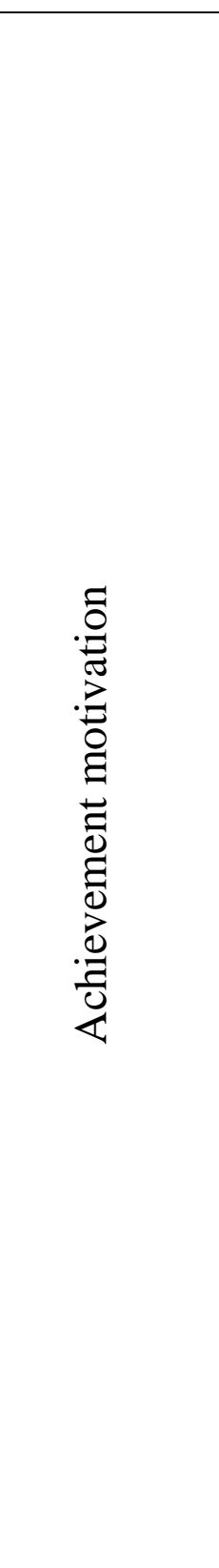 } & $\begin{array}{l}\text { Creativity, } \\
\text { imagining and } \\
\text { innovating }\end{array}$ & 0.277 & $\begin{array}{c}\text { Regression } \\
\text { Residuals } \\
\text { Total }\end{array}$ & $\begin{array}{l}2403.320 \\
6266.835 \\
8670.155\end{array}$ & $\begin{array}{c}1 \\
198 \\
199\end{array}$ & $\begin{array}{c}2403.320 \\
31.651\end{array}$ & 75.933 & 0.001 & $\begin{array}{c}\text { Constant } \\
\text { Creativity, } \\
\text { imagining and } \\
\text { innovating }\end{array}$ & 52.03 & $\begin{array}{l}3.34 \\
0.189\end{array}$ & 0.526 & $\begin{array}{l}15.57 \\
8.71\end{array}$ & $\begin{array}{l}0.001 \\
0.001\end{array}$ \\
\hline & $\begin{array}{c}\text { Thinking } \\
\text { interdependently }\end{array}$ & 0.354 & $\begin{array}{c}\text { Regression } \\
\text { Residuals } \\
\text { Total }\end{array}$ & $\begin{array}{c}370.582 \\
5599.573 \\
8670.155\end{array}$ & $\begin{array}{c}2 \\
197 \\
199\end{array}$ & $\begin{array}{c}1535.291 \\
28.424\end{array}$ & 54.013 & 0.001 & $\begin{array}{c}\text { Constant } \\
\text { Creativity, } \\
\text { imagining and } \\
\text { innovating } \\
\text { Thinking } \\
\text { interdependently }\end{array}$ & $\begin{array}{l}4.03 \\
1.20 \\
1.18\end{array}$ & $\begin{array}{l}4.03 \\
0.20 \\
0.24\end{array}$ & $\begin{array}{l}0.38 \\
0.31\end{array}$ & $\begin{array}{l}9.88 \\
6.01 \\
4.84\end{array}$ & $\begin{array}{l}0.001 \\
0.001 \\
0.001\end{array}$ \\
\hline & $\begin{array}{c}\text { Benefit from } \\
\text { experience }\end{array}$ & 0.393 & $\begin{array}{c}\text { Regression } \\
\text { Residuals } \\
\text { Total }\end{array}$ & $\begin{array}{l}3408.861 \\
5261.289 \\
8670.155\end{array}$ & $\begin{array}{c}3 \\
196 \\
199\end{array}$ & $\begin{array}{c}1136.219 \\
26.843\end{array}$ & 42.330 & 0.001 & $\begin{array}{c}\text { Constant } \\
\text { Creativity, } \\
\text { imagining and } \\
\text { innovating } \\
\text { Thinking } \\
\text { interdependently } \\
\text { Benefit from } \\
\text { experience }\end{array}$ & $\begin{array}{l}33.55 \\
0.86 \\
1.09 \\
0.84\end{array}$ & $\begin{array}{l}4.31 \\
0.21 \\
0.23 \\
0.23\end{array}$ & $\begin{array}{l}0.27 \\
0.28 \\
0.23\end{array}$ & $\begin{array}{r}7.78 \\
4.00 \\
4.58 \\
3.55\end{array}$ & $\begin{array}{l}0.001 \\
0.001 \\
0.001 \\
0.001\end{array}$ \\
\hline & $\begin{array}{l}\text { Striving for } \\
\text { accuracy }\end{array}$ & 0.417 & $\begin{array}{c}\text { Regression } \\
\text { Residuals } \\
\text { Total }\end{array}$ & $\begin{array}{l}3619.562 \\
5050.593 \\
8670.155\end{array}$ & & $\begin{array}{c}904.891 \\
25.90\end{array}$ & 34.937 & 0.001 & $\begin{array}{c}\text { Constant } \\
\text { Creativity, } \\
\text { imagining and } \\
\text { innovating } \\
\text { Thinking } \\
\text { interdependently } \\
\text { Benefit from } \\
\text { experience } \\
\text { Striving for } \\
\text { accuracy }\end{array}$ & $\begin{array}{l}32.21 \\
0.66 \\
0.89 \\
0.72 \\
0.41\end{array}$ & $\begin{array}{l}.26 \\
0.22 \\
0.24 \\
0.23 \\
0.14\end{array}$ & $\begin{array}{l}0.21 \\
0.23 \\
0.19 \\
0.19\end{array}$ & $\begin{array}{l}7.56 \\
2.96 \\
3.67 \\
3.03 \\
2.85\end{array}$ & $\begin{array}{l}0.001 \\
0.001 \\
0.001 \\
0.001 \\
0.001\end{array}$ \\
\hline
\end{tabular}


It is clear from Table (4) that the variables of achievement motivation are creativity, imagining and innovating, thinking interdependently, benefit from experience and striving for accuracy, which are ranked according to their importance and impact on the dependent variable "achievement motivation". The predictive model of creativity, imagining and innovating for achievement motivation explains $(27.7 \%)$ of the total variance, and the two predictive models of creativity, imagining and innovating and thinking interdependently for achievement motivation explains $(35.4 \%)$ of the total variance. The predictive model of creativity, imagining and innovating, thinking interdependently and benefit from experience for achievement motivation explains $(39.3 \%)$ of the total variance. The final model, which includes creativity, imagining and innovating, thinking interdependently, benefit from experience and striving for accuracy, explains $(41.7 \%)$ of the total variance. Thus, the four predictive models of achievement motivation explain large percentages of variance, where the values of the square of the multiple correlation coefficient $\left(\mathrm{R}^{2}\right)$ ranged between $(0.277-0.417)$.

Table 4 also shows the results of the analysis of the multiple regression variance ("P" ratio) of the four models. This table shows that there is a statistically significant effect at level 100.0 for the four independent variables "Creativity, imagining and innovating, thinking interdependently, benefit from experience and striving for accuracy". Table (4) shows that the impact of the four predictive variables on the dependent variable is significant statistically as " $\mathrm{T}$ " values of each of them are significant statistically.

The regression equation that can predict the score of "achievement motivation" can be formulated through the degrees of "creativity, imagining and innovating, thinking interdependently, benefit from experience and striving for accuracy" as follows:

Achievement motivation $=32.21+(0.66 \times$ score of creativity, imagining and innovating $)+(0.89 \times$ score of thinking interdependently $)$ $+(0.72 \times$ score of benefit from experience $)+(0.41 \times$ score of striving for accuracy). 


\section{Discussion of results:}

It is clear from Table (3) that the validity of the first hypothesis is achieved where there is a positive statistical relationship between the habits of mind and the achievement motivation in the study sample. The result of this hypothesis is consistent with the results of the study of (ElQudah, 2014), which showed that there is a positive statistical relationship between the habits of mind and achievement motivation.

As Eva, 2002) suggests that the use of mind habits serves to increase vitality and help to achieve better. In this regard, Campbell (2006) noted that the habits of mind are the best way to teach intelligent thinking behaviors, help learners to organize themselves and drive them toward achievement, help them find solutions in their relationships and workplaces, and develop problem-solving skills.

Squire \& Jan (2007) explained that the habits of mind develop scientific thinking and drive towards learning enjoyment, achieving academic success, and increasing academic achievement. Wiersema \& Licklider (2009) noted that learning first occurs in the mind through specific mental habits that facilitate learning and increase its memorization. Individuals seeking lifelong learning exercise flexible thinking, creativity, self-discipline, adapt to the learning environment, employ previous experiences, and use language skills, and also showed the existence of a statistically significant correlation between the exercise of the habits of mind and increase the academic achievement.

The results of the first hypothesis may seem logical. The presence of positive, high and statistically significant correlation coefficients between the habits of mind and achievement motivation may be due to the fact that such habits help the individual to build goals, desire and strive to achieve them, and competition to achieve the criteria of excellence. The assistant lecturer has the ability of "communicating with clarity and accuracy, striving for accuracy, learning continuously, sense of humor, listen with understanding and empathy, creativity, imagining and innovating, thinking interdependently and benefit from experience" and they are reflected positively on his ambition, and the achievement of his goals, awareness of his abilities and motivation of his achievement. In this regard, states that the habits of mink make students more focused and responsible and allow them to lead their learning, and they help 
them also to organize thinking processes, increase learning abilities and improve skills, and drive them to achieve goals.

The results of the regression analysis showed that it is possible to predict the achievement motivation through the habits of mind. Table (4) shows that the habits of creativity, imagining and innovating, thinking interdependently, benefit from experience and striving for accuracy are positive predictors of achievement motivation, as these variables explains a percentage of $(41.7 \%)$ of the total variance in the scores of habits of mind.

The result of this hypothesis is partly in line with the study of(ElQudah,2014), whose results indicate that creativity, imagining and innovating are positive predictors of achievement motivation.

The result of this hypothesis can be interpreted in the light of the findings of the second hypothesis. Table 3 shows that the correlation value between creativity, imagining and innovating, thinking interdependently, benefit from experience and striving for accuracy was higher than the correlation values of the remaining variables of studying the achievement motivation, thus the creativity, imagining and innovating, thinking interdependently, benefit from experience and striving for accuracy were appeared again in the three models of regression. The results of the regression analysis showed that creativity, imagining and innovating, thinking interdependently, benefit from experience and striving for accuracy are positive predictors of the achievement motivation. This can be explained in the light of the positive relationship between the habits of mind and the achievement motivation as shown in Table (3). The more the individual has the ability to innovate and imagine, i.e. his or her ability to upgrade his style, his ability to imagine himself in different roles; this pushes him to achieve his goals. Thinking interdependently increases the individual's ability to understand others and interact with them. This will help further research to improve learning and achieving goals, and the use of past knowledge increases the activity of the individual to proceed with achieving his goals without falling into the previous mistakes, and the striving for accuracy and the ability of the individual to work continuously and professionally without mistakes, all contribute to the motivation to achieve the tasks required and then attain the goals.

The environment for Demonstrators and assistant Lecturers requires such habits because it helps them to accomplish the tasks required of 
them such as performing lectures, preparing masters and doctoral theses, communicating with the supervisors as well as attending conferences and scientific seminars, and searching for new scientific sources, they need to make a new scientific contribution to their scientific research, Also, these habits are necessary because they help them face their problems and motivate them to drive for achievement Motivation.

\section{Recommendations and Suggested researches:}

\section{(A) Study recommendations :}

In light of the results of the study, the researcher suggests some recommendations that can be used, and can be summarized as follows:

1. Including educational activities that contribute to developing mental skills that make up habits of the mind in university courses

2. The necessity of emphasizing the members of the university's supporting body to work on developing students 'habits of mind through models, theories, and strategies that urge the development of thinking.

3. Reorganizing the content of university curricula so that they are given an adequate opportunity for students to practice rational habits, including the various skills it contains.

4. The study recommends that those who prepare professional programs for members of the university's aid committee pay attention to designing programs based on mind habits, because the development of these habits has become an urgent need to establish these habits as a social personal value that transforms society into a developed society that solves problems and makes the right decisions.

\section{B) Suggested researches:}

It can be derived from the theoretical basis upon which the current research was based and the results of a number of proposed researches that can achieve more depth in analysis and study as follows:

1. The effectiveness of a training program to develop some habits of Mind a sample of the Assistant Lecturers in University.

2. The effectiveness of a training program to develop some habits of mind to achieve professional competence among the members of the Assistant Lecturers in University.

3. Study habits of the mind and their relationship to decisionmaking among a sample of the Assistant Lecturers in University. 
4. Study habits of the mind and their relationship to psychological burning among a sample of members of the Assistant Lecturers in University.

5. Habits of the mind and their relationship to motivation for achievement among high school students.

\section{References:}

Abbas, E., \& Faisal, N. (2015). The Habits of Mind and their Relation to the Level of Professional Performance among Kindergarten Female Teachers. Amman: Arab Society Library for Publishing and Distribution.

Abd Al-Fattah, A. J. (2017). Teaching Habits of Mind, Their Relationship to Positive Behavior of Social Studies Teachers in Lower Basic Stage In University District- The Capital (Amman), Journal of Curriculum and Teaching.6(2),30-51.

Abd El-Hamid,F., \& Abo Hashim, M. (2007). The factorial structure of of intelligence in the light of Gardner's classification and its relation to bothself-efficacy, problem solving and academic achievement among university students, Journal of Faculty of Education (55), 171-242.

Abd El-Moaty, A. H. (2018). The habits of mind produced by faculty members at the University of Assiut and its relationship to decision-making. Journal of Faculty of Education. 4(2),130155.

Abd El-Raouf, M. (2016). The Predictive Mind of Habits of Lateral Thinking. Arabic Studies in Education and Psychology, Issue (77).

Abd El-Wahab,S. Sh., \& Al-Waeli, I. H. (2010). The relationship between the productive habits of mind and emotional intelligence and its effect on the academic achievement of secondary school students of both sexes. Journal of Faculty of Education, Mansoura University.5(2),145-170.

Abdel Maqsoud,A. (2016). A measure of motivation for achievement for children and adolescents. Cairo: The Anglo Library.

Abdullatif, R. (2015). The Habits of Mind and its Relation to the Problem Solving Ability of Outstanding Students in the King 
Abdullah II Schools of Excellence in the Hashemite Kingdom of Jordan, Master Thesis, Jordan, Mu'tah University.

Adams, M. (2006). Power Point, Habits of mind and Classroom Culture, Journal of Curriculum Studies. 4(38),389-411.

Al-Karaki, W. (1996). The Relationship of Study Habits and Their Trends and the Achievement Motivation by Academic Achievement of students of Mutah University, Master Thesis, Mutah University, Jordan.

Al-Qudah, M. F. (2014). The habits of mind and its relation to the achievement motivation among the students of the Faculty of Education, King Saud University, Arab Journal for the Development of Excellence, Issue.3 (8), 33-59.

Al-Rabighi, K. M. (2015). Habits of Mind and Achievement Motivation, Jordan: Dar De Bono for Teaching Thinking.

Al-Shemari, N. (2010). The habits of mind and emotional intelligence and their relation to academic achievement among the students of Al-Jouf University in the Kingdom of Saudi Arabia, $\mathrm{PhD}$ thesis, Yarmouk University, Irbid, Jordan.

Arndt, A. (2009). Problems with Problem Solving: Assessing Written Solutions of Mathematical Habits of Mind .University of Nebraska-Lincoln, Digital Commons, University of Nebraska Lincoln.

Campbell, J.(2006). Theorizing habits of mind as a framework for Learning the association for active educational researchers.

Cohen,L. \& Manyon, L. (1990): Research methods in social and educational sciences, Translation: Kawther Kojik and William Taoudros. Cairo: Al-Dar Al-Arabiya for Publishing and Distribution.

Costa, A., \& Kallick, B. (2000). Discovering and Exploring Habits of mind A Development Series, Book 1,Alexandria Association for Supervision and Curriculum Development.

Costa,A., \& Kallick,B. (2003). Exploring the habits of mind (first book), translation: Dhahran National Schools, Dammam: Dar AlKitab Al-Tarbawi Publishing. 
Costa,A., \& Kallick,B. (2005). Classification and maintenance of the habits of mind, translation: Dhahran National Schools. Dammam: Dar Al-Kitab Al-Tarbawi Publishing

Culler, A. (2007). From Dropouts to Higher Achievers: Habits of Mind, PhD Thesis.

Eid, Y. M. (2015). Arab scale of achievement motivation. Cairo: The Anglo-Egyptian Library.

Erian, S. A. (2010). The habits of mind and the skills of social intelligence required for the teacher of philosophy and sociology in the 21st century. Journal of Studies in Curricula and Methods of Instruction. 25(4),155.

Eva, G. (2002). Toward Dynamic Assessment of Reading: Applying Megacognitive Awareness Guide to Reading Assessment Test, Journal of Research in Reading, 25 (3),283-293.

Hajat, A. I. (2008). The Habits of Mind and Self-Efficacy among the Students of Seventh and Tenth Classes in Jordan and their Association with some Demographic Variables, Master Thesis, University of Jordan, Amman, Jordan.

Mahmoud, W. (2018). Contribution of the habits of mind in predicting the positive thinking among the university students. Journal of the Faculty of Education, University of Benha, $29,116$.

Mousa,F. (1987). The motivation measure for achievement for the preparatory, secondary and university levels. Cairo: The Anglo Library.

Nofal, M. B. (2006). Common Habits of Mind among the Students of the Basic Elementary Stage in UNRWA Schools in Jordan, Journal of the Teacher-Student, 9 (1)132-155.

Petri, H., \& Govern, J. (2004). Motivation: Theory, Research and Applications, Thomson Wadsworth, Australia.

Salama,I. \& Rasmi, E. (2012): The Habits of Mind among the students of the tenth primary class and its contribution to the ability to solve the mathematical problem, Arab Gulf Message Journal, 127, 56-68. 
Squire, K., \& Jan, M. (2007). Developing Scientific Argumentation Skills with Emotional Intelligence as a mediator. Journal of Science Education and Technology, 14(3), 5-29.

Tayseer, S., \& Ahmad, M. (2011). Study of the Habits of Mind among University Students in relation to the variables of University and College Experience and Gender, Educational Journal, 26, (101), 247-283.

Wiersema, J., \& Licklider, B. (2009). Intentional Mental Processing Student Thinking as a Habit of mind, Journal of Ethnographic, Qualitative Research, 3 (1), 117-127.

\section{الإسهام النسبى لعادات العقل فى التنبؤبالدافعية للإنجازللدى عينة \\ من أعضاء الهيئة المعاونة بـالجامعة \\ و وسام إبراهيم محمد}

الملخص:

تهدف هذه الدراسة إلى التعرف على العلاقة بين عادات العقل و الدافعية للإنجاز، وكذلك إمكانية

التنبؤ بدافعية الإنجاز من خلال عادات العقل، وذلك لدى عينة تكونت من ( . ب) من أعضاء الهيئة

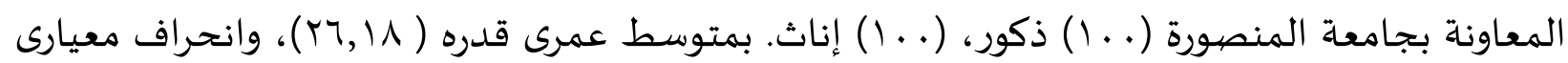
قدره (†),r)، وقد تم استخدام مقياس عادات العقل (إعداد: الباحثة)، ومقياس الدافعية للإنجاز (إعداد: الباحثة). أوضحت نتائج الدراسة أنه توجد علاقة دالة إحصائياً موجباة بين عادات العقل " التواصل بوضوح ودقة، الالتزام بالدقة، الاستعداد للتعلم الدائم، روح الدعابة، الإصغاء بتفهم وتعاطف، الابتكار والتصيور والتجديد، التفكير التعاونى-التبادلى، والاستفادة من الخبرة" و الدافعية للإنجاز، وقد أوضحت نتائج تحليل الانحدار المتعدد أنه يُمكن التنبؤ بالدافعية للإنجاز من خلال الابتكار والتصيور والتجديد، التفكير التعاونى-التبادلى، الاستفادة من الخبرة، والالتزام بالدقة وقد تم تفسير نتائج الدراسـة فى ضوء الإطار النظرى والدراسات السـابقة. الكلمات المفتاحية: عادات العقل - الدافعية للإنجاز -أعضياء الهيئة المعاونة بالجامعة 